SF 287

. $\mathrm{H92}$

Copy 1

\title{
HORSE OF ANOTHER COLOR.
}

\section{A $\mathrm{A}$ L OGY}

OF THE

24

Nature and Life of the Horse

A COMPLETE EXPOSITION OF THE

MYSTERIES OF HORSE-TRAINING.

B Y MOSES HUMBER.

PUBLISHED BY THE A THOR.

1881. 



\title{
THE HORSE OF ANOTHER COLOR.
}

\author{
ANALOGY ,
}

OF THE

\section{Nature and Life of the Horse \\ SHOWING THE}

Clouded State of His Intellect, His Trains of Thought,

His Grievances and the Cause of His Unruli-

Ness; also the Only True Method by which HF can be Taught; a Com-

PLETE EXPOSITION OF THE

\section{MYSTERIES OF HORSE TRAINING,}

\section{SHOWING}

How to Cultivate the Beauty; Hints to Breeders on the Best Kind of Harness adapted to His use, AND how to Arrange it to Prevent Choking, etc.

By MOSES HUMBER.

\section{Buffarol}

PUBLISHED BY THE AUTHOR.

I88I. 


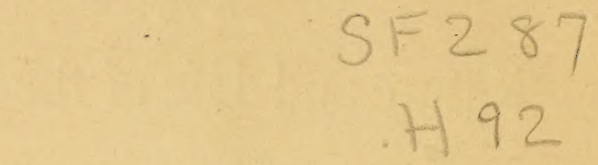

THE COURIER COMPANY,

Electrotypers, Printers and Binders, BUfFALO, N. $Y$. 


\section{CONTENTS.}

Page.

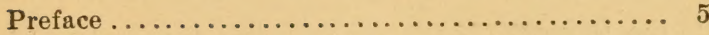

The Influence of the Voice............... 9

The Cause of the Balk.................. 11

The Cure of the Balk.................. 18

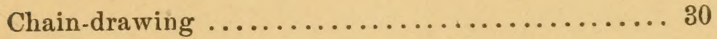

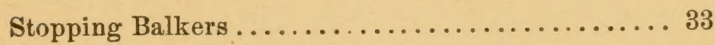

Seesaw Teams........................ 34

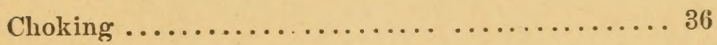

The Kicker . . . . . . . . . . . . . . . . . . 39

The Final Secrets of Horse-training........... 43

Colt Breaking...................... 50

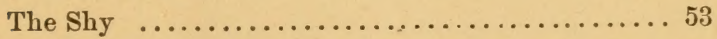

The Horse for General Purposes............. 55

On Training the Trotter.................. 56

Training the Horse to Follow his Trainer ....... 59

On the Use of the Whip .................67 67 
Page.

The Cultivation of Beauty, or the Beauty of Good Treatment .....................69

Notes on Breeding..................... 72

General Remarks ..................... 73

The Stable ...................... 84

On Cleaning. ...................... 85

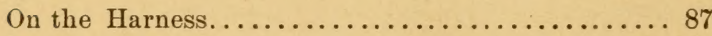

Choking-Cause and Cure............... 90

Head Fixings. . . . . . . . . . . . . . . . 92 


\section{P R E F A C E.}

TIHE horse is acknowledged to be one of the Inoblest members of the animal kingdom. His frame is a perfect model of elegance; a concentrated energy, easily managed if kindly treated; proud, but persevering, he has been one of the most valuable aids to human civilization. The power that some individuals possess in promoting obedience and cultivating the most useful qualities of the horse is admitted to be truly surprising; but here the matter usually ends, leaving the remainder enshrouded in traditional mystery. This may be attributable to the fact that the real horseman has but little time to devote, and is ill-prepared in literary accomplishments to remove the veil from such a knotty and entangled question.

In the preparation of this work, it has been the writer's aim to throw some light on this seemingly impregnable mystery, and, in so doing, 
I feel confident that I am removing what has long been a perplexing barrier to the progress of horse-training. This work treats mainly with the heavy, or semi-heavy draught team, in the ranks of which all miscalled bad horses usually find their way. Although I have endeavored to throw sufficient light on the nature of the horse, and this so-called obstinacy, to enable the horseman to judge pretty nearly what is best to be done under all modern difficulties, whether heavy draught horse, carriage, saddle, civil or military. Though in reading the secrecy of the art, the observances may appear many, yet it is only by a detailed explanation the horseman can obtain a satisfactory view of the subject. It is here shown that the secret of horse-training lies in becoming familiar with and working upon the notions, intellect and sensitive feelings, or rather the inner, in place of the outer, horse; such knowledge places the horseman in a position to be guided by an agent unseen by the ordinary observer; hence the power of some individuals over others; and for the horseman to reap the benefit of this 
work, he should read, study and become familiar with all of the different forms of training, as herein set forth. This done, he should be competent to train the horse in a short time to any given point, or know the reason why. In bringing this work before the horse-working public, I trust that it will not only prove beneficial to man, but shield that noble animal in question from ill-treatment, to which he has been too long a victim; for the person who yields to anger, and vents it upon the horse, will never know his own ability in the horsetraining art.

Therefore it behooves us not to be guided_by our own petty grievances, but act the nobler part, observe laws, and train in an intelligible form, so required by the clouded intellect of this noble, useful and inoffensive animal. 



\section{THE HORSE OF ANOTHER COLOR.}

\section{THE INFLUENCE OF THE VOICE.}

In speaking to the horse the horseman is apt to commit himself through the gruff tone of the voice, applied with a view to cause fear and more effectually impress his authority; but this is erroneous, for fear lasts but a short timeis at best only a confused interruption, is then superseded by a case-hardened indifference.

'The horse utilizes the voice and finds in it a true indicator of the intentions of the horseman-a forerunner of deeds that are to follow -so that if we do not ill-treat physically, the voice indicates it ultimately, so that the horse imagines the horseman is only restrained from violence until his anger becomes more inflamed; this suspense causes fretting and is deadly poison to the nobler, steady, unerring action of the horse.

Take, for example, the horse of a timid 
nature: The horseman may do his utmost in guarding against any ill-treatment for weeks, with a view to promoting a cool, steady action of the horse, but all of no avail-he is still fretting; but if the driver will reflect back a moment he will remember he has been in the habit of throwing out, now and again, a berating word ; this, then, is the agent that has secretly set all his endeavors at naught, for the horse has been listening to every word that has fallen from his lips, and continues to contemplate, as he has often hitherto read by bitter experience, the dreaded intention of the ulterior. This being the case, it is absolutely necessary that , words cease with the deeds.

There is no denying but man is capable of overcoming all modern unmanageable horses if he will observe laws that lead to that end; and, whilst pointing out those laws, I am laboring under the unpleasant knowledge that his abilities will be materially impaired if the voice is not free from all scolding tendencies. The voice plays strange freaks in its influence over the horse, for although when raised in anger it is very annoying and disturbing, yet it tends only to berate and beat down, and has no power what- 
ever in bringing about that higher standard of ready compliance. And it should be borne in mind by the horseman that (so peculiar is the nature of the voice that it carries with it no force and falls to the ground unless accompanied by the whip, etc., as herein set forth), though the voice alone would not produce balking or kicking, yet it probably furnishes half of the causes from which those habits are engendered. I may mention that in turning either way you will facilitate ready comprehension and compliance by throwing the voice rather in the direction you wish them to go; but if you throw it in the opposite direction it is apt to bewilder and mislead the horse in his blindfolded way of working.

\section{THE CAUSE OF THE BALK.}

Before commencing to cure the balk it is essential that the horseman have some knowledge as to its cause. Its chief cause may be said to arise through excitement, from being whipped, clubbed, hallooed at and urged on repeatedly to draw at immovable objects; or, in other words, vainly endearoring to accomplish impossibilities. At such times the horseman will 
adopt a blustering course of action. This blustering is supposed to enhance drawing, but the result of which we shall hereafter see, for the horse, after witnessing a few times the result of the stick, becomes terribly excited to find he is again fastened to the spot; and no matter how crushing may be the ill-treatment, he is invariably bound to abide the result and receive the same at the hands of a too often rebellious, unreasoning driver. When we reflect on how easy our own quietude is affected by the anger of others, with all our intellect, equality of rank and ability, and without the slightest blow being inflicted, we may consider we have but a feeble idea of the magnitude of the horse's feelings when he is subjected to clubbing over his head and ears without reserve; but, on the contrary, with a view to inflict the most bitter and burning pangs of pain and terror possible. With this in view help is sometimes called, and formidable weapons, such as handspikes in the lumber woods, and pick-handles on railroads, are frequently brought into use. The hor'se soou comes to view those stickings to mean nothing. more nor less than an onset of harsher treatment, and when stuck, or he has reasons to believe so, 
although probably it requires but a small effort on his part to overcome the difficulty, he listens to the tone of the driver's voice, and, if angry, he knows too well his fate is sealed.

Should he find this the case it causes a tremulous fear, his thoughts are then riveted on drawing this ill-treatment on. In passing throngh and landing on the other side of it, of course he receives his customary amount of ill-treatment; and, feeling relief from the same, we will suppose him to draw and succeed in removing the load from the difficulty. The driver is then led to suppose that it was this ill-treatment that caused the horse to draw, and by laying it on hot and heavy, grasps the hope that in the near future the animal will not hesitate a moment in complying with his wishes; but how absurd such an idea, for at the next difficulty the same loss of time, the same annoyance and root of all evil, ill-treatment, will hare to be repeated again and again; and as a rule the horseman shuts his eyes to those glaring facts.

When we see those beatings rivet the horse's attention, and that his whole aim is to draw them on and land on the other side of them, instead of going on with his work, we camnot 
14 THE HORSE OF ANOTHER COLOR.

fail to see that the ill-treatment is the sole cause of the difficulty. In short, to control by force, means to force out of control in all cases.

The value of the horse is frequently impaired in this way; he will do something wrong and the horseman will give him a whipping. 'This disturbs his quietude, causing unsteady action; this brings down more ill-will and he is whipped again for this unsteadiness, the sheer result of former beatings, and, in the near future, if this treatment is not changed, he is pronounced balky, unmanageable, or an animal of little value. Of course the horse is saddled with the cause of the difficulty, when it is shown man is the instigator of it, and the more unsteady he is, the more he is made so, and the more dilapidated he appears, the more he is made to appear, and the more he is held in disfaror, the more reason there appears to be to disfavor hin. The horse's case is a hopeless one, for the demands of an ill-disposed horseman have no limits, and under all reverses he is expected to be full of pride and gaiety, so as to show himself off to the best advantage to attract the eye, which, of course, is an impossibility under existing circumstances, and, altogether his lot in life is 
hard indeed to depict; and if he could speak and defend himself, we should have such a terrible tale of suffering, it would not fail to gain sympathy from a heart harder than stone.

The horse is a proud, gay, but, in many respects, a timid, deer-like animal, and it may be said of him, as it is said of the peacock, he is conscious of his attractive carriage, and let him be ever so lean, in outward appearance, inwardly he aims to maintain this majestic standard. The horseman is too often ready with the whip, or other means, to disrespectfully impair the loftier aims of the animal.

Should he find this the case, should he find extreme measures adopted, he must adopt extreme action; hence the balk, kick, rear, etc. His noble nature will not admit of being so ground down without showing signs of disapproval. He is willing man should take absolute control, if he will learn to effect this by proper and becoming means; then why should man be so oppressive, when to cause so much fear and anxiety, to endeavor to grind and cower him down and place the iron heel of tyranny upon his neck, when this kills all the better appearance and quality of the horse, and, at the same 
time, is a great disadvantage to man's own interest? If the driver is puzzled to know what to do, when in difficulty, he should aim to keep on the side of leniency, for by so doing, the better, steady actions of the animal will be maintained, for to treat the horse with harshness is an error of the deepest dye and should be at once discontinued, for it accomplishes nothing, but destroys every particle of the better qualities of the animal.

The fifty-dollar horse requires the same treatment as the five-hundred dollar horse; he may require a little more whip, but, if ill-treated, to him it is equally disheartening, and leads to the same erroneous effect.

With the few foregoing remarks before him, the horseman may see that the horse possesses feelings in this respect similar to those of his own kith and kin, and should be treated accordingly. He is proud, gay, high-spirited, possessing keen, sensitive feelings, and is so tenderhearted that the voice alone is sufficient to stab him to the core. Although we cannot teach him without the whip, yet it is necessary we proceed with care, or we are producing a rod for our own back, for thoughtless, harsh treat- 
ment causes confusion, and its venomous sting cannot be overcome only by a lengthy course of lenity, namely, until the horse perceives by long experience he need not fear any harsh treatment. Then, and not till then, can he be brought to work with all the steady, determined fire and energy peculiar to his race. And no matter how long the time it may take the horseman, to obtain this quietude, he should proceed with a steady purpose; improvements are straight ahead of him, and he cannot miss them. Though in commencing to remove the fears of an animal that has long been a victim to illtreatment, more especially at his own hands, improvements will be slow for the first ten days, or so, but after this the horse's ears will show signs of relief, will occasionally take an observing form; it is not until after this that the main strides for the better take place. It is just as natural for the horse to jump, kick, rear and balk, whilst undergoing, or under the influence of, ill-treatment, as it is for the pig to squeal whilst under the operation of having a ring put in his nose; it is simply each one's method of expressing his pain.

As a rule it is, on the horse's part, erroneously 
supposed to take the form of a fight; but suppose we class it under that head, we see it is by man forced upon the animal, and if we did not fight him his attitude would be changed; having nothing to fight with, he would not fight the air and would soon reach the level warranted by surrounding circumstances, but if we continue to fight with him, it is the backbone of the difficulty, and accomplishes nothing as has been clearly shown. Thus we, to a certain degree, discern the horse's trains of thought, his grievance and the cause of his unruliness.

The horseman is now supposed to have read the foregoing part of this work, and the following instructions are not only for the cure of the balk, but a course of training that should at all times be adopted.

\section{THE CURE OF THE BALK.}

In removing the balking habits in the horse the first and main thing to be done is to train the horse to obey the starting word. The horseman will accomplish this by giving the starting word and simultaneously allowing the whip to fall on each horse, alternately, if a double team, until both horses show equal signs of readiness to start, no matter if one be balky and the other 
not, for they should be welded together, so to speak, and both bound by the same" discipline. The driver's attention to this matter of starting should be as fixed and unvarying as that of the engineer, who has first to turn on the steam to set the machinery in motion. By applying the whip simultaneously with the starting word, in a few days it will be found that as soon as the reins are handled the horses will show wariness and will be ready to go. When this readiness appears the whip should be applied very lightly or withheld altogether for a short time, for it has accomplished its mission, and if persistently continued will drive out of control rather than draw in. By this the horseman will see that the attention only is needed to be permanently fixed, that the whipping is administered on a sliding scale. It is a well-known fact that men are puzzled and wanting in ability to control the actions of the balky horse. At this point this difficulty is overcome by applying the whip simultaneously with the starting word, as it livets the horse to obedience and teaches him exactly what is wanted and strikes at the root of the evil. The greatest drawback with horsemen in this matter is that they are apt to refrain from lightly whipping an easily excited horse, 
at least until they allow him to start without it, but this is not properly instructing the animal, although a becoming act, it caunot be denied, but the nature of the horse does not admit of its adoption; therefore, the horseman should remember a faint heart never gained a fair lady, and that it is not the whip when becomingly applied that produces uncontrollable excitement, but the anger and cruelty of man as exhibited in hallooing and indulging. in the use of unlawful weapons. 'This hesitation to lightly apply the whip is fatal to our aims, for inaction of man produces inaction of the horse, and so each one seems to be waiting for the other to lead off, and as the driver is holding back to inflict a severe lash presently if his orders are not obeyed, so is the horse preparing and waiting to receive it, rather than going on with his work; whereas, by nsing leniently the whip on each horse alternately, it welds them together, teaching them to be ready and move on as soon as the word is given. 'This habit once established in the horse, he will unhesitatingly obey, proceed on and set all excitement to naught, it having no chance to edge in as the load is taken from the difficulty before excitement appears on 
the scene of action, and will soon become a matter happily forgotten and unknown to the animal. The driver should attend to this training, to start off at first, more particularly with a light or no load; but as this training will have no effect for a few days, and excitement is still rife in the horse, do not whip but once or twice, accompanying the starting word, and give the order's to stop in seven seconds after; stand forty seconds and repeat, he will draw after a little while, and the oftener you start him under this system the sooner you will gain complete control over him.

The horseman will remember it is not the severe lash that will facilitate his aims, but a smooth, lenient and daily returning to the same course of training. The following of these instructions will remove the balk from any horse. But this training should not be neglected to-day and to-morrow an effort made to bring up the loss by a severe whipping, for the horse is of a forgetful nature and cannot be effectually trained by starts; knowing nothing of ways and means, his course of life is aimless and unsteady, therefore, he requires the cantious guardianship of man to correct his blunder's. 
The word alone so much depended on to be sufficient to instruct the horse to draw, is too vain and weak and falls to the ground; for, as shown, when spoken as is usual to the balker, in a gruff manner, has a tendency to confound and act quite the reverse of what it is meant for. Hence the necessity of practicing the whip to fall with the word, for it supplies the spark necessary to give force and action at that point.

Thus we see there is no necessity for any of the ill-will or ill-treatment so commonly and erroneonsly adopted, for there is no denying the willingness of the animal to labor; all he asks is some steadying, some close instructions, some definite and standing line of training that he can comprehend, in place of being whipped to-day for something, to-morrow for something else, and the following day for another grievance, and at the end of a week returning to the original, and again departing on the same rounds.

In applying the whip with the starting word, it may be found, in five or six days, that the horses will become restless and want to go before ordered. Should this take place they should receive a moderate pull with the lines, and should this cause a backward move the whip 
should instantly fall on them whilst in the act of backing; and should the horses-repeat, the driver must repeat, and meet act for act with lessening force until they stand still. In this way he will gain control over the movements of his team. At that point train to exactuess and good order.

In accomplishing tasks of heary drawing the starting should vary a little. As it requires a few seconds for the horses to place themselves into pusition, they should be allowed a little time, and if handled with care they will habitually begin to draw in about five seconds after receiving their orders. In applying the whip with the starting word, until the horses are thoroughly trained, they will make an attempt to start at the first instance where the whip is in the habit of falling, and the next moment they may be seen to hesitate. When this is apparent the whip should be withheld at the first instance and brought to fall immediately on their wavering; and to meet this difficulty effectually the driver should be prepared at the next start and cause the whip to fall at the exact moment this wavering is in the habit of appearing, without waiting to see if it is being 


\section{THE HORSE OF ANOTHER COLOR.}

carried into effect this time or not, for it is plain that such habits exist and should be removed. Or, in a general way, a light and varied whipping should be spread over the five seconds allowed between the word and the start in heary drawing, and even after, to promote the most powerful drawing.

In those struggles the team should receire no words except to go on or stop, the whip shonld do the remainder, moderately falling on all flinchings or laggings behind; and the starting word should be spoken with a double meaning, such as "get up, my boys." In this way we aroid causing any pointed, special probe that may breed fretting and thwarting tendencies; it also should be spoken in one continuous tone of voice (and no secondary utterances), or the horses are apt to suppose tl.eir orders are countermanded. Finding the driver not firm in his decision will cause them to waver for an explanation. And in delivering those orders the driver should not look at the horses' heads, but rather muffle or throw the voice on the ground between the two; in this way he does not draw away the horses' thoughts, but allows them to direct it more on their occupation, which means 
energy and a more healthy working inclination. And again, the starting word shonld not be in anywise a squealing cut of nature, and changed to befit the occasion; for instance, if there is no load to start, it may be delivered in a light, mild way, or a chirp will answer the purpose here; but, on the other hand, in starting loads, and according to the force of the draw required to start them, the power of the voice should be increased in a proper ratio, until the powers of the animal are taxed to their utmost, then should the roice assume a full, bass strain; in this way it is a lead off and quickens the horse.

The adrantage of the rather lengthy, singletone utterance is, that it seems to somehow determine and fortify the horse for a more lengthy, conquering draw, and its strong or bass tone points to and tells the horse the power of the draw required for the occasion. And this is of no small adrantage, especially in taking the first draw at a strange object, for without some forerunner the horse is at a disadrantage, knowing nothing of what he is hitched to, and he soon becomes familiar with its changing meaning.

I have pointed out these simple methods for the driver's observance, but he may, of course, 
practice them as time, place and circumstances may offer; he should bear in mind, however, that to facilitate ready, most powerful and timesaving drawing, we should observe laws which are enticing and invigorating to the animal. Though the voice points to the weight of the draw, yet, unless by a tried, careful and neverdeceiving driver, the horse is wary and shy of bringing abruptly into play his full powers, for fear of something giving away and pitching him headlong, and it is probable that not until the third encounter will he apply his full strength. The horseman should allow and wait patiently for those testing preparations.

The horse is a powerful and a noble animal, full of fire and energy, capable of accomplishing great and astonishing feats, and is well adapted to his purpose; and the horseman that will support and encourage the growth of this fire and agility, is the person he will most readily obey. This means in drawing at an immovable or nearly immovable object, he wishes and should be allowed to start it with a sudden, determined effort. This is reasonable, for how absurd wonld it be to persuade a man in lifting a heavy article to lift for seven or eight seconds before applying 
his full strength. Therefore, the horse should not be forced into a slow, undecided' move by tight lines, for it not only dampens his energy but his strength is materially impaired, as the life of the object is wanting. And, moreorer, the horse is wary and shy of displeasing the horseman by adrancing ahead and pulling the lines in what appears to be a forbidden direction. Therefore, it is the driver's duty not to deter the horse's movement, but to come behind, support, steady and see that the fiery move is backed and maintained. This he will accomplish by practicing letting the whip fall with reserve along the horse's back, say in two seconds after the encounter-the draught; or, as already pointed out, at any time any flinchings may be apparent the whip should promptly meet the waver. 'There is one thing very essential about meeting these warerings, we should endearor to meet them at the exact moment they are in progress, for this is the sure and only method whereby they can, by its repeated application, be promptly removed. But the horseman should guard against allowing the whip to play against the hind legs, as it is detrimental to good drawing; and the team should not be allowed to 
draw at those immovable objects more than about six seconds and receive the word to cease. This will keep good order and they will be more willing to draw again, say in forty seconds. We should not excite and confuse the horse by urging him on to struggle and draw more than the above-named time, for the horse, like man, is willing to make a vigorous effort, but becomes disheartened with a useless prolongation of these distressing attacks, and the horseman may console himself with the fact that the most powerful drawing is accomplished at the moment the attempt is made. And in such cases the word to stop as well as to go on should be of a rather full, say swelled, tone. In this way it imparts a sort of stimulating effect -keeps abreast of the.times, and is a somewhat novel way of congratulating the horse' on his powerful abilities.

This, in fact, is far more acceptable to his noble nature than any childish patting. The same will apply to the average moveable lnad, say on the wagon, surmounting a hill, going through soft places in the road, etc. And starts of heavy drawing in general, the driver should offer the horses the lines in a liberal 
advancing manner, thus encouraging their fiery ambition; but he will again come behind and see that it is backed up, applying the whip at the moment of any flinchings or stopping before orders. In this way he will weld his team together, bringing about a smooth, onward course of proceeding, for each horse requires to place confidence in the other; and, in order to keep abreast support, shoulder to shoulder, and never flinch from duty, each horse depends on the driver to so weld them together. And, indeed, it is not far that we have to look to see how powerless they are in this matter themselves; yet it is of vital importance to their burdensome way.

Horses, when exerting themselres severely, say surmounting a hill, etc., should not go longer than thirty-five seconds, and be stopped two minutes for wind, and, if badly pumped out, a little more; and in very hot weather, when panting, double that time, at least, for how galling and distressing must it be, when, as is too often the case, he receives a severe lash or domineering growl, while having to struggle on in a weakened state through insufficiently recovering his wind. Then, again, he should 
not linger longer than to replenish his full requirements of wind, until the summit of the hill is gained, or the termination of similar encounters, as the horse is then warm, and in a state of elasticity, and his mind is bent on his work, and he is more eager to encounter and combat the difficulty.

\section{CHAIN-DRAWING.}

Balky horses, when drawing with chains, will, sometimes, suddenly swing around towards the driver, and in so doing will slacken the lines, so that for the moment he has no control. When this takes place, he should step forward and give the nearest to him a moderate blow across the nose with the whip-stock, cansing them to return to their respective positions.

And should they shy from him, they should receive a sharp pull with the lines, brought back and bound to the head in the required directions. Then, again, the balker has a habit of putting his nose over the other's withers. In this again the driver shonld endeavor to bring the whip-lash or stock to fall across the nose. This difficulty will be removed by smoothly and repeatedly applying these in- 
structions. The driver should not stand by and negligently witness these unpleasant practices without adopting some known remedy. At the same time we should not hurl spite at the horses for this apparent craft, for they never sought it; this was forced under their notice by a long-standing misrule. I may mention that, excepting the point of the nose, the hor'se should receive no blows about the head, nor along the neck in front of the collar, for the head should be set aside, as a flower, to be handled only with care, or as the butterfly that loses its beanty at the touch. In drawing with chains, the horseman should bear in mind and lengthen the traces, so that if the chain slips the whiffletrees will clear the heels; for should they, in flying forward, strike the heels, it may not only cause pain and lame the horse, but it causes a shyness of drawing, but you will lighten the dranght again, by shortening, after everything has a firm grip.

When the horseman has a heavy dranght to make, he should start the team forward, tightening the chain, so that the horses may have some knowledge where to meet the draught before receiving the final word, and it should not 
escape the driver's notice to see that they both stand prominent and even. In this way he will keep exactness and good order; and the team should have good footing, at least for the first few steps, or otherwise should be exempted, if not willing to draw. As a rule they do not like to draw, heading down hill, as they are conscious of their great strength, severely trying the tackling, and aware of the danger of being pitched headlong should anything give way. The horse will also flinch from drawing with a high draught, as it tends to rear him up, destroying his strength; and by experience he is umpleasantly conscious of the danger of choking. The driver should keep a lookout for these thwarting tendencies, as to enforce drawing causes confusion and breeds erroneous working habits in the horse. Sometimes when receiving orders to stop, one horse will make a step back. This habit should be removed by applying the whip at the time the back-step is made, at the same time give a light pull with the lines to ease the other back a little, standing them even and training to an orderly position. Rearing balkers need but little comment here, but simply this: they are whipped too 
sererely; and if applied sufficiently, light and not departed from, it will be the means of preventing it.

This is rather a shy, reserved, harmless act, far different from the dangerous, wicked kick, and they are probably the very best of horses when cured of this habit.

\section{STOPPING BALKERS.}

Some horses are in the habit of stopping when their weight of draught is suddenly changed for the heavier. This difficulty will soon be overcome by applying the whip at the moment the halt is being effected; but if it should require a powerful draw to again start, they should receive the word to stop with the first stroke of the whip; for as soon as the halt takes place they are out of position to take a heavy draw, but should receive two strokes each after they are stopped, but no more. Those few timely strokes will cause them to continue on to avoid them. The cause of those stoppings probably is that the horse is seized with a sudden fear, thinking the horseman is about to pounce upon him with violence, so that he becomes in a measure spell- 
34 THE HORSE OF ANOTHER COLOR.

bound ; and, as already shown, his aims, strange to say, are bent on passing through and landing on the other side of this ill-treatment; so that as long as force is resorted to, the difficulty will never be removed. As this work will show, no transaction can be relied upon in getting them to start again for a few days, until the instructions herein set forth take effect, namely, by applying the whip with the starting word. Train the horse to start when told, and the stopping will disappear. This will also apply to roadsters that are in the habit of refusing to go.

\section{SEESAW TEAMS.}

We frequently find teams with a habit of seesawing each other while in the act of drawing. This difficulty will soon be overcome by bringing the whip to fall first on the one then on the other at the moment the backward move is made.

There is something worth observing about meeting those flinchings; that is, if we meet them with the whip at the exact moment, we impress our alertness, promote caution, and the horse is soon seen to make a desperate effort to avoid carrying them into effect; but if we allow 
them to perform these tricks unrebuked, it is no matter how severely we whip afterwards, it will have no force, whatever, in effecting a cure, for the horse seems to receive it as a small part of such treatment. He is unaccountable, heir to, and there is not a shadow of an indication whereby we may detect that he ever gleans from it any other meaning. We must endeavor to debar the act, for all other transactions become null and void. The horseman should avoid or at least guard against endearoring to hold the horses even by tight lines, for this only cramps and destroys the energetic morement, and has no effect in working a cure. There is no doubt stay-chains should be attached to the wagon, and it would be beneficial in all cases of heavy drawing if something of the kind could be attached. The prevailing idea is (but I beliere an erroneous one) that it tends to cause balk, but when this difficulty is overcome the case is altered; and, as already pointed ont, each horse depends on the other to keep abreast and afford unflinching support to his co-working companion, for it happens that if one ceases drawing it dampens the energy of the other, as it makes him cautious of bringing into play his full 
strength, being then off his guard. In meeting these uncertain contingences, the horse is also conscious of his great strength and wishes to take a firm and never-yielding hold of his load. Then again the horse finds difficulty in this way beyond the detection of man, and staychains would prevent this annoyance even at the hands of the most thoughtless young men and boys.

\section{CHOKING.}

Choking is a frequent and terrible occurrence with heavy draught teams, and with the majority of drivers the matter is disregarded as though it was only a stumble, and the horse is on some occasions even whipped and held responsible for the mishap, as being brought about through holding his head down and working in a sluggish manner; but if the horseman would only reflect for a moment, how terrible must be the heart-rending pangs of the time present, he would refrain from proving himself such a baneful tyrant. Fancy this struggling animal's thoughts on finding his wind abruptly shut off, and he is striving to gain it, and every second's delay heaps terror upon ter- 
ror, pain upon pain; but alas! it is too true, the grasp of one of the most dreadful of deaths cannot be shaken off; his powerful muscles quiver at the felon's grasp until life, in despair, is extinct, and he falls dead at the feet of his driver, a victim of the wanton neglect of man.

Choking occurs to some horses eight or ten times in the course of the day, and all through harness ill-adapted for them, are even liable to choke at every heavy draw. How this may effect the lungs is not my profession to say, but we may fairly suppose them to be strained and injured far beyond their strength and all reasonable-imagination. After encountering such anguish a few times, if there was one spark of cowardice in his nature, this alone should be sufficient to cause him to refuse to draw, knowing, by sad experience, he is open to such calamities; but to the credit of his noble family, he is in position again as soon as he gains his feet, ready to struggle on, and endeavor to avoid the anger and supply the craving demands of his ruler, and ever now and anon to encounter the same distressing pangs over again, and, for all he knows, even unto death. (See remarks on the harness for its prevention.) Yet the 
horseman is too often ready and rife to force his despotic sway to the bitter point, erroneously supposing that the horse has nothing to complain of, and that any disobedience of orders is sheer stubbornness. When we look and closely discern the many grievances the horse has to contend with, and scores of others beyond the detection of man, we have some knowledge of the canse of his disobeying orders. When we see the exciting effects of harsh words; when we see the tremulous, unsteady, frightening effects of ill-treatment; when we see that man fails to lightly apply the whip and instruct the horse to obey the starting word; when we see that man fails to steady and correct by applying the whip at the right moment in all flinchings, wavers, sudden stops, seesawing, etc., allowing his team to indulge in and mature a confusing, disorderly habit of working; when we see they are against drawing, heading down hill, with a high dranght, bad footing; when we see the baneful effects of the choking, saying nothing of internal ailments, that may be working their own secret course, we can but conclude that writers must be lamentably at sea in this matter when they try to prore that taking the horse into a 
shed and throwing or teaching him to lie down at will, or fastening up one front leg and so driving, will cure the balk. What on earth has this to do with staying the influx of those thwarting tendencies or removing the wounded remembrance they leave in their wake? This is the reverse of a cure, for it only drives the horse to a more and more aghast position and commit acts he wonld never think of only in moments of desperation.

\section{THE KICKER.}

It is the nature of the horse to kick. This is more especially apparent while in an entire state; the mare coming under this head, it is her we are mostly troubled with. It is simply absurd and misleading to say that one certain act will cure kicking, for it is, like the habit of balking, engendered by various grievances, headed by the despotic rule of man, so that in curing it the driver should guard against showing any haughty tendencies, adopting a systematical course of training, such as is pointed out in this work. If he has been in the habit of illtreating and frightening the animal he should reverse this, say for ten days, and bring her 
mind to a more tranquil state, for it is our duty to preserve the plucky nature of the animal; whereas, if she has reasons to suppose the horseman is prejudiced against her, she is not in a fit state to undergo the operation and admit of a cure with a ready dispatch, as it would have too much the appearance of endeavoring to crush by main force; would tend to destroy every spark of pride and higher aims she may still possess, leaving tokens of deep, spiritless degradation, and, moreover, the horseman is already aware of the fact that to control by force means to force out of control. This, like all other bad habits, we must catch and debar the act, or no cure. To explain the plan :

Suppose we fetter and fasten one hind foot to one front foot, so that when she kicked the action of the hind foot would trip the front foot from under her, throwing her headlong with affright. If this could in any way be effected every time she kicked, the habit would decamp in a most basty fashion, because the thoughts would be drawn from the use of the heels and occupied in what was going to happen the front part, and the outcome of the act would soon work its own downfall. But this class of fet- 
tering could not be adopted only when standing; but the horseman when on tre wagon at home may adopt a plan to answer this purpose. For example: Take a hame strap; buekle it on the inside front leg, just above the knee, with a loop to it; next fasten a ring to the irons at the end of the wagon pole; take, say a rope plow line, pass one end through the ring at end of the pole, again through the loop strapped on the knee, and fasten to the end of the pole, leading the opposite end back to be held in the hand with the lines; this is to trip her if possible whilst the heels are yet off the ground. It is an easy matter to trip in this way and completely debar the act, but this, again, could not be adopted only when on the wagon; but we may take other steps; we may have help, and one can drive and do something to cause the kick, while the other is prepared with something to push the knee forward and so effect the fall; or, if the horseman is in a position, he may push the knee forward with his foot. Should he be so situated, he should act and not hesitate a moment, for hesitation is fatal to good horsetraining, and the horseman may console himself by the fact that he is acting on a proper, 
most sure and ready cure. I may mention it is beneficial to vary the knee operated on.

The horseman should not become impatient at the slow progress of improvement, for this habit, once established, cannot be thoroughly uprooted by an expert using ordinary means, in less than six or eight weeks. Give her several falls daily and she will become more and more afraid to kick, and finally the habit will dwindle out and disappear; but you should have something on the knees to save them in falling.

Though the nature of the habit causes it difficult to cope with, yet when the nature of the animal becomes thoroughly understood, it will be found that there is no effectual cure for those habits equal to meeting and debarring the act, so prominently alluded to in this work.

It should be the horseman's aim at all times to draw her thoughts away from the use of the heels. With this in view, tapping the front leg or the nose would be beneficial; or, for the sake of illustration, while going through one of her kicking spells, throw suddenly down in front of her a buffalo robe, or something to cause atfright. The kicking would cease for the present with surprising abruptness. 
When I say that one certain act will not remove the kick, it means that we must not shut our eyes to the fact that this is her way of showing there is something unbearable, headed by the haughtiness of man, so that if we continue to govern by the harsh word and severe lash, we are only clashing the canse and the cure together, making matters worse instead of better.

\section{THE FINAL SECRETS OF HORSE-TRAINING.}

In perusing this work the horseman will see laid out before him a systematical course of training, where he, in removing bad habits of the horse, is to cope with and apply the whip, etc., in the act. Carry this out according to instructions, and it is no matter how bad the balk, or how bad the sudden stopping without orders, or how bad the seesawing, waver, flinching, or faltering in any way (where the horse is not out of position) ; it is no matter how wicked the kick, those instructions will be found to be a never-failing remedy. It is impossible for the horse to nullify or heedlessly disregard this alert course of action; so to speak, he is compelled to bow to the superior abilities of man. 
This, then, is the final secret and science of horse-training, and the only true method by which the horse can be minutely corrected and taught. It is from men holding such knowledge springs all the traditional accounts of the art, for it is no matter what we wish to teach the horse, it can be accomplished by keeping down confusion and keeping those facts in view. This being the case, I believe I have fulfilled my promise, namely, to throw some light on the semi-impregnable mysteries of horse-training.

I would wish to impress upon the horseman's mind that he adopt this course of training, for in this way he can, in a few weeks, train the horse to serve all modern tastes and requirements, and that he give up the idle hope of obtaining information whereby he may immediately control the movements of an excited, unmanageable horse. With all my close study and experience in his nature, notions and habits, I candidly have to confess I fail to discover such a method, and I do not believe it could escape my knowledge and lie concealed in the background. To support these views, we find the intellectual faculties of the horse so clouded that he sees no motive for what he is doing; he works according to his accustomed habit; 
whether this habit is with or against men's wishes he sees no interest and gives no thought of ascertaining ; neither has he the power to remove those habits, so that if changed, it must be done by some outside agency. To bring about a reformation of those habits, requires a lengthy course of instruction. We must get him to perform again and again, until the habit becomes an established fact; then smoothly keep it alive. Thus we see the monstrous folly of endeavoring to turn the course of nature by violence. The success of horse-training depends on whipping and acting at the right moment, and not the severe lash. If we allow the child, in endeavoring to count a hundred, to continue on and get mixed up with his twentyten, twenty-eleven, twenty-twelve, and then whip him for his inability, it has nothing to do with teaching; we must point out the exact place where the numbers have to be changed.

I will here mention a few of the transactions adopted to cause the horse to draw. Probably one of the best plans is to throw a coat over his head, or, in other words, blindfold him. This seems to allay his fears, as, likely, he finds some relief, being shut out from the target-gaze 
of man; then, again; if we cover his body it reems to allay his fears as though he supposes it will screen him from violent attacks; then, again, take a small stick and tap him on the inside of the front leg below the knee; this odd act probably unhinges his aghast thoughts for a moment, and having to move his legs to avoid the taps that are falling on them, will somesometimes suddenly start off; or giving the true one a light touch, instructing him to lead off, enticing the other on, is beneficial ; or giving the reins to a stranger to drive; or throwing the voice from, in place of towards, the horses in giving order's; these transactions may promote the horse to draw; then, again, no reliance can be placed in any of them; it is only done to trick, with no certainty of success. When we see the horse is relieved by being shut out from the gaze of man, we can but see that patting is rather injurious to an excited horse, for by this he detects man's attention is fixed on him. (Never pat the horse but little, for by nature he is inclined to be let alone.) It would be more beneficial to turn from him and speak to a person at a distance, or hammering 
at the wagon, etc.; his burning brain would then find a moment's relief.

I scarcely need mention that the horseman will see by this work that severely beating the horse is quite the reverse to our aim; but to abruptly withhold all weapons is not the best course to adopt, for the horse imagines formidable weapons are still lying about handy for use at any moment; this is still firing excitement. The best thing to be done at this stage is to take a piece of brushwood, and, better still, if full of green leaves; use this freely with every starting word, etc.; this is to allow the horse to detect to his entire satisfaction that the weapon in use is harmless. This piece of brushwood, if convenient, should never be dispensed with in driving a bad balker, for its influence over an excited horse is something wonderful, and it is to be regretted its powers are so little known among horsemen, because it is opposite to the course they are in the habit of steering. By the use of this, and whistling and singing to show good humor, I have known the very worst cases of balk removed in one day. I contend that a horse laboring under a tremulous excitement cannot be brought immediately to 
work in a tranquil, collected, determined manner; or, in other words, no immediate control. For fear there may still be any doubt on this point, we have it on record and by tradition, that some men will enter a stable, closing the doors after them, and in the short space of a half hour, may be seen with the most vicious animals, quite subdued and lying at their feet, fondling them like a puppy-dog.

This sounds very well on paper, but the sufferings and anguish of that inoffensive animal is something appalling, for he, as it were, is put through an operation nearly depriving him of life, and falls exhausted to the floor. This is repeated, again and again, until the horse becomes so weak he cannot rise, or have the good sense to lie still rather than again face his doom. To subdue the horse in this way is held up as something surprising, but with close observation, we see that the animal does not fulfill any useful orders; neither has this anything to do with quenching the venomous effects of a tremulous excitement. It is nothing more nor less than a forced inaction, something the horse has no power to avoid. There is no science in this; there is no cultivation of energy, beauty and 
the higher stages of usefulness, and moreover a half hour is not immediate control ; it is absolute brute-overpowering, destruction and death, and I decline to expose the methods adopted to effect it, it being of no use whatever to the horseman.

It frequently happens we find one horse more balky than the other. I will make a few remarks on this query. The driver is familiar with the main cause of the balk, namely, ill-treatment; he is also instructed to impart equality, to aroid inflicting any pointed special probe, for should he drift into the habit of concentrating his attention and whipping the one, he is still driving the balking one more and more into the mire. The true horse, finding the driver has something to call his attention and vent his anger on, feels himself exempted from the exciting situation. He remains collected and prepared to draw when required, and the driver, in his erroneous endeavor to bring about a unanimous movement, is widening the breach between them, if such is possible. Now if the horseman were to reverse this treatment, center his attention and use violence on the true one, and holding out leniency to the balker, the upshot would be the 
true one would soon become balky and the bulker by degrees would become true, though there is probably not a horseman in civilization but would abhor such a change, yet he would be equally as well justified in the one as the other. This will bear out the instructions that the horseman, in training his team to obey the starting word, is to apply the whip to each horse alternately until each appears equally ready to go as soon as the lines are handled, or other signs are made, no matter if one be balky and the other not, for they must be welded together and both brought under the same disciplinary rules.

\section{COLT BREAKING.}

In regard to colt breaking, I do not propose to dwell on it at length. It has been my aim to throw sufficient light on his nature and mental faculties to enable the horseman to overcome all modern difficulties. The colt, as a rule, is an inoffensive know-nothing beast; he may jump, rear, sit down on his haunches, etc., but the horseman should endeavor to pursue steadily on and tire him out. This does not arise, as is often supposed, from stubbornness, for as yet 
he knows nothing of stubbornness, but it solely arises from being hampered, tied and jumbled up in such a fashion; in fact stubbornness is a feature that has no existence in the horse family, until it is forced by the poisonous effects of bad management. The colt should never be unhitched when he becomes rather unpleasant to work with, for there is no better way of quieting him down to work and harness than fatigue; and should it pass from weeks to months to train him to work properly, he should never receive a harsh word or a severe lash, and in return he is sure to become a true, faithful working animal. The driver's first aim should be to teach him by a light touch to start at the word; the same should he stop before orders. By being tied to the other horse, he will soon learn to stop, but do not tie him by the bit, or you will hurt him, make him afraid, and cause pain without profit. See that the trained horse leads off in every way. Never attempt to drive the colt ahead, or it will cause fretting and confusion, as he knows nothing of what he is doing. A colt, when driven on the land or near side at plowing, when stopped, will hug his head into the furrow-horse's side, at the same time turn- 
ing his hind part out and crosswise of his work, which places him in an awkward position to start again. This will be averted by throwing little lumps of dirt and catching him about the off or inside fore-arm, or take a little switch and touch him along the off or inside whilst in the act of placing himself in that crossed position. This transaction will make him believe that by backing out he leaves this inside open for attack. In this way the difficulty will soon disappear, but if you strike on the out or near side, it would be difficult to cure, as the colt wonld endeavor to turn that side more and more from you. As has already been pointed out, it is the mare that mostly kicks, enhanced by her entire state. This being the case, we cannot fail to observe that breaking fillies in the spring of the year, and in their season, would be liable to set the kicking habit afloat. This is quite possible, for I believe, by investigation, it would be found that in nine cases out of ten it is spring-broke mares that kick, especially in being driven with a horse, for sometimes she shows fondness for her companion, at other times she is quite the reverse. Either of those spells may promote kicking. Then again there is no doubt that 
other causes help it, such as the rattling and entanglement of the harness, etc., and as soon as she begins to kick is very apt to receive harsh treatment for the act, which, by the way, is all that is wanted to frame it into an established success. Should the filly commence to kick with one leg, it is probably caused by the plowlines striking or working in the vicinity of the flank. Shonid this be apparent, drive her on the other side for a time, and, with care, it will disappear.

\section{THE SHY.}

It is somewhat amusing to see how effectually the shying horse has been cured on paper, but somehow it cannot be effectually done outside the pages of a book, and when that day comes we shall have a woful change in the horse to that beautifully adapted animal we have to-day. 'To effectually cure the shy, we should have an animal something after the nature of a liuge tortoise, that shrinks into his shell and defys injury by any modern attack, or as the beast clothed with a skin that a musketball cannot penetrate; then we should have a horse with nothing to fear. But so long as we 
have that thin-skinned, glossy-coated animal, so open to injury, so obedient, so tenderhearted, that he starts and trembles at the mere voice of man, so long shall we have a timid, shying horse. There is one thing that will abate the shy, that is if the horse is subject to ill-treatment; for instance, the balker, being subject to this, in him we have not a shying horse, because he is cowered down to a stolid indifference to all around him; but if we liberate and cultivate the better qualities of the horse, all his life and spirits are preserved, and the life is the shy, and the shy is the life, and cannot in no way be separated. I do not believe there is any benefit derived in driving him up to a roadside object that he is afraid of, as, probably, the next time he is more inclined to give such objects a wide berth. When the horse is afraid, the driver should, if convenient, stand between him and the object of his fear; and, should he take fright and endeavor to break away, the driver should be cold, collected and confident, and no matter how near the anticipated danger, the same quiet, commanding tone of voice should be maintained, for shonld the driver become alarmed, the horse knows it 
in a moment by the faltering change of the roice, be it ever so slight, and should he find this the case, he is stricken with a double shock of alarm and will run panic-stricken.

Many a life and limb would be saved, if women and children could be kept from squealing and aggravating excitement. I have stopped horses abruptly after running a couple of humdred yards, solely through maintaining a cold, steady tone of voice. The driver should be well supplied with good bits and lines, and never leave his team without both being tied, for one should not be called upon to hold by the head the sudden move of his own body and also that of his companion.

\section{THE HORSE FOR GENERAL PURPOSES.}

I contend we have no horse to answer this purpose effectually, for, in supporting the higher life and better appearance of the animal, it is necessary we be guided by the requirements of his nature. We see that smooth uninterruption promutes this end, not to force the horse to depart unexpectedly and abruptly from any accustomed course of proceeding, as it disturbs his quietude. We find the liorse for general 
purposes a victim to this changing system which is a galling destruction to both willingness and attraction, for to-day he is trained to slow and muscular trying ability, and to-morrow this is abruptly set aside and he is called upon suddenly to adapt himself for a high speed of travel. The horse, in his more or less stiffened state, finds it an unpleasant duty and degrading to his noble nature unless handled with care. Men, at those times, are apt to drive too fast, whipping too severely, and on one certain part of the body or legs, forcing him into an ill-shaped sort of a shuffling gait, destroying that beantiful, liberated all-fours move, fostering that disfiguring, pointing-back position of the ears. These unhorsemanship traits will be removed if you whip on different parts of the back, with a view rather to entice than to force, and the horse will uphold speed almost equal to being driven by force, for there is nothing that can compete with the will.

\section{ON TRAINING THE TROTTER.}

In training the trotter, endeavor to mature self-energy in the horse. This you will accomplish if you pull up in your training spins, so 
that he has still plenty of fire in hand. Never over-drive the hor'se, or in a short time you will injure his abilities rather than otherwise convince him that he can satisfy your aims by a fair and vigorous exertion. Whip smooth in your training spins, say every fifteen or twenty seconds. Never draw a severe lash; if so, it sort of passes ahead of the horse, and he will despair of ever keeping pace ahead and avoiding it. Never whip only in such a way that it causes a little more pain than the present exertion of the body; but, if to increase speed, whip in quick succession; in this way he will move in a graceful, uninterrupted form, centering his attentions on, and working his all-fours in a clean, dexterous style. Never allow the whip to strike the legs, or the horse will become conscious of its severity, increasing with the swifter move of the leg, and, moreorer, he is inclined to shorten them up. Nothing whatever should touch the legs; allow him to stretch them with all confidential freedom; apply the whip on various parts of the back; never use a Dutch collar; it is too loose, is detrimental to a fine, polished move, as it saws across the points of the shoulders; use a nice, 
narrow bearing collar, pinching close in, down along the sides of the neck, with the draught about six-tenths up from the points of the shoulders to the withers, free from all encumbrance; the outer sides, and more especially the points of the shoulders, should have unlimited scope. A blind-bridle is preferable to an open one, because the trotter is apt to get into difficulty when going at the top of his speed through his all-fours mode of locomotion. We should endeavor to center his whole attention to the working of his feet, and glancing forward down to where he is going to step; this cannot be done to perfection while an open bridle is worn, for, in spite of all that may be done, his attention will be cast over his back to the motion of the whip and the driver, the reverse of where it should be. By observing these rules you will cultivate a willing energy and attain the extreme highest point of speed, causing the horse to be a dangerous and respected antagonist on the race-course. 


\section{TRAINING THE HORSE TO FOLLOW HIS TRAINER.}

To teach the horse to instantly leave his grain and follow his trainer out of the stable, across fields, along the road, around the yard, etc., by the mere word, is the masterpiece of all horsetraining, for it should be borne in mind that the horse is as free as the bird in the air to depart if so inclined, and it requires the most masterly control to restrain him, yet by an expert it can be brought to such a state of perfection that the horseman may, so to speak, almost forfeit his life should the horse refuse to follow or disobey his orders in any way. To accomplish this difficult feat, it is necessary that we dispense with the lines, as it were, turning the horse adrift, for this necessitates purely a rocal command; and have but one horse to drive, say one horse and cart, and walk or stand on the near side; say you order the horse to stop or back up, the whip-stock is instantly with those orders brought to tap him on the front leg below the knee, and if to cease backing or go ahead, the whip accompanies each word in like manner and is instantly brought to fall across the rump; then comes the order to "gee off;" he again, 
simultaneously with the word, receives a push on the shoulder-blade or a little poke in the nose with the whip-stock, and should this cause the horse to increase his steps, he is steadied and held to a proper gait and position by the check-rein or other means for that purpose; and if required to "haw to," the horse is taught to obey by the whip-lash falling over the withers and down the off shoulder-blade, and if this is not sufficient, is again directed by the check-rein. Follow these instructions, and frequently stepping out and walking in front of him, you will in time train him to fullow you.

This, then, is the outline of the most difficult feats of all horse-training. The horseman will now be familiar with the instructions in driving with the lines to apply the whip with the starting word, as otherwise the word alone is null. This word, under the system of driving with the lines, is the main word that takes the form of a vocal system of control. The horse is taught to obey the move of the lines mainly for the remainder, but in driving without lines all these words, namely, "go on," "stop," "back up," "cease backing," "gee," or "haw," have to be accompanied with a similiar application 
of the whip to sanction, bind, govern' and teach. The outcome of a lengthy course of this training is first by the tapping of the leg; with the word "back," he is riveted to obey and backs out of the stall, etc., unhesitatingly when ordered, and should he blunder, the word "whoa" is responded to in like manner, and finally to "haw" or "gee" towards his trainer, as the case may be. The horse thoroughly trained in this way all stubbornness vanishes in thin air, and he will obey those words hundreds of yards away if he can hear and comprehend their meaning. It is seen there is no special effort made to train to follow, but to gain a varied and sweeping command.

It is erroneously supposed that the horse can be taught and trained to follow by leading, and having a long whip, now and again throwing it around his hind-quarters, making him follow close up, but this is child's play and has nothing to do with explaining the science of horsetraining. The science of horse-training lies in striking at the right moment and finding out, to a nicety, how much force is best adapted for the occasion, to rivet, bind and draw in, not to frighten and drive out, or our authority is lost. 
By this leading, like the lines, he is taught to obey the move of the halter-strap, and when the halter is removed he is lost, having nothing: to steady him; but if we turn him adrift and teach him to look solely to the word for his guidance, his guidance becomes the same, harness or no harness.

Strictly speaking, there is no doubt this following notion is brought from the Old World. Take, for example, the system of working the horse in many parts of England, namely, driving in long strings; the colt is broke to follow the leading horse to and from his work, and from the leading horse to the driver. Thus we see the following system forms one of the principal branches of his early training; then again he is broke solely to obey vocal command, so that an expert horseman, following the avocation of working with one horse and cart, can in a short time train any of those horses to follow him, without departing in any way from their early training. Hence we see there is great difficulty in teaching to follow under the American fashion of driving the horse with reins, as he knows nothing of this following system.

In endeavoring to throw all the light possible 
on the art of horse-training, I have a few more remarks to make connected with this following system that may be useful to the horseman. I have pointed out that this is the most difficult and highest point of control man can obtain. The outcome of this masterly command is that it is no matter how balky or unmanageable the horse may be at the start, at the winding up he will draw at an immovable object at intervals of once a minute for the whole of the day. In explanation to this, it is in this work shown that the horse's way is aimless. Knowing nothing of ways and means, he looks to man to guide and steady him, and when we reach this masterly control required for the horse to follow, we also stand in this masterly position of guiding and steadying, for the horse has become to know that he is guided with such judgment, such, care, such fine discipline, that he seems to renounce all self-claims to the will of man and obeys his order's in every way. Now there is every reason to believe that if the horse could be surrounded or cased in, so that he could not twist or turn either way, that this would have such an effect on pacifying or removing the unsteady fears of the horse that balking would 
64 THE HORSE OF ANOTHER COLOR.

almost, if not totally, vanish. But as this walling-in support cannot be adopted, we have to work on some artificial means which is obtained in this way: The horseman seeing the horse a little agitated at not being able to proceed on and fulfill his orders, touches him with the whip-stock first on the front side of the front leg, below the knee, the same on the hind leg at the back of the hock, giving the word "whoa" in a mild tone with each touch; repeat this three times on the near side legs, pass by the head, drawing the whip-stock lightly across each front leg as you pass; apply the same instructions on the off legs, and return by the head, touching again the front legs as you pass; perform this every time any uneasiness is apparent, and the animal will draw, cold and collected, as long as he is told. I may mention it usually takes at least three months to obtain this control, because all habits must be reformed, all disobedience must be completely uprooted and unknown to the horse, and once thoroughly trained he will obey and follow a child or any one just the same as the ordinary horse will obey the word "whoa" or "back," etc. This being the case, it will set at rest the supposition that it is ac- 
complished by drugs. Some advocate teaching the horse to lie down at our bidding and remind him of his subdued situation, but this is erroneous, for in building up vigor and willing compliance we camnot afford to kill all this by such conflicting, confusing, enforced inaction to the working horse. This becomes at once a dead letter, and should not be indulged in. I maintain that to train the horse to follow his trainer is the most difficult of all horse-training. For example, here is a simple circus trick recorded and held up as a leading specimen of some men's ability: Form a circle, put a bridle on the horse, with a strap or rope fastened to it, sufficient in length to fasten around your body; take a stick in your left hand and a whip in your right, walk on the near side, circling the horse to the left, and every time he puts his left front foot to the ground give it a tap with the stick you have in your left hand, keeping him in motion with the whip; in this way you will cause him to catch up and appear lame on this leg. Now comes the final trick: the horse enters the circle and is sent jumping poles, circling to the right; after awhile is stopped and turned, the poles are removed, and he commences circling 
to the left; he now astonishes the assembly by his sudden and pretended lameness, as if to say, "Look here, I cannot perform any more tonight; see how lame I am." Presently he is again stopped and turned; his leg is examined, and found to be perfectly sound; with this the trainer remarks, "Ah! you dog, you are trying. to get a sell on me," at the same time throwing the whip over his rump, sending him circling to the right, and jumping the poles with no longer any signs of lameness. Now this is supposed to be sagacionsness on the horse's part, matured by some unknown, ingenious plan of the trainer's, but, as seen, it is simply done by training to go lame whilst circling to the left. In training to this, tap the horse very light and await the result of time; thus you will preserve all the gay, cheerful attractions of the horse. By this we see that training the horse in a circle is quite inferior to commanding the horse to follow in an open field, because the circle, etc., compels the horse to keep in close proximity, relieving the trainer of the most difficult part of all horse-training. I do not propose to dwell on circus horse-training; my subject is the useful working-horse. 


\section{ON THE USE OF THE WHIP.}

In whipping the horse the horseman should guard against allowing the whip to platy around the vicinity of the flank, flaying the sheath or other private appendage, for, as an hereditary right, he claims protection of those parts, and it is dispiriting if he finds the horseman so wanting in knowledge and feeling as becomes his high intellectual standard.

The balky horse should not be whipped on the hind legs, as it causes them to become hampered and forced too far forward to control the action of the body in drawing; and again, while drawing, the muscles are then hard, which means increased pain. 'The most honorable way to strike the horse is on the back, and this is undoubtedly the place where he should receive his whipping. I cannot, in writing, point out the force of the whip best suited under various circumstances, but I trust this work will throw sufficient light on the sensitive feeling and nature of the animal to enable the horseman to judge for himseli.

I have prominently shown that the whip should, at all times, be applied with care and reserve, and by adopting this course you will 
find that it will greatly enhance the accomplishment of heavy draws with punctuality and dispatch. Some companies forbid the carrying of the whip, but this does not accomplish all that is aimed at, namely, to procure good treatment for the animal, from the fact that the driver who cannot be trusted with the whip is scarcely competent to handle a team without one, for, not being able to enforce observation of his orders, he becomes angry, will halloo and pull the lines, which means disturbance and ill-will; his team will bear enmity toward him, will appear sour and discouraged. The driver will also seek revenge at set times and in out-of-theway places, which is here shown is completely at sea in the way of instructing the animal. This work will bear me out that the whip can in no way be dispensed with in driving the horse, because, as shown, the word to the horse becomes completely null, carrying with it no force whatever; consequently, he can receive no instructions except from the whip; it is only by the whip we can brace, steady and weld them together, smoothing their burdensome way. I have proven to my satisfaction that the horse is not averse to the whip when becomingly ap- 
plied. I will here mention that af́ter the team is started and traveling along the road, etc., you should keep their minds bent to their work by lightly applying the whip every few minutes. You should as carefully watch the movements of your team as the fireman watches his steamgauge.

\section{THE CULTIVATION OF BEAUTY, OR THE BEAUTY OF GOOD TREATMENT.}

The many difficulties that may be avoided by having a knowledge of the art of horse-training are beyond estimation, for by knowledge and care we prevent restiveness, plunging and destructiveness, causing unnecessary expense, or prevent, as is too often the case, the horse laming or otherwise injuring himself; we prevent loss of time, annoyance; we prevent all those little tricks, such as seesawing, wavering, etc.; teaching the horse to work in orderly, horsemanship style, and the horseman maintains his reputation as a driver. Then comes on the better appearance of the horse, which the ears may be said to take the leading part, although the graceful, attractive or unattractive movements of the horse accompany the ears respect- 
ively. These features appear according to the treatment the horse at such times is subject to ; in the ears is found a true indicator of his mental sufferings, for if the ears are carried pointed back he is being ill-treated, is subject to a sudden severe lash, or has recently been a victim to such treatment; and it is to be regretted we may daily see a large percentage of horses laboring under this gnawing, cankering, and neverabating disease; and while this is apparent we find that the graceful curve of the neck is lost, as his thoughts and glances are then aiming over his back on the whip and the driver. In this way the forward part of the neck and erown of the head is carried too high. This beautiful accomplishment, the curre of the neck, can only be formed to perfection when the thoughts are at liberty and he glances rather down in front of him, though many horses do not possess that admirable set-off, yet, if handled to the best advantage, the outlines will frequently appear on almost any horse in company with the better move of the animal, for with care his aim is elevated and he adrances with a relieved, bold, observing front.

There is, no doubt, room for vast improve- 
ment in the art of cultivating the attractions of the horse, and by becoming masters of the art of training, we become competent to mature the beauty also, for a knowledge of the art means better treatment of the horse, and better treatment and beauty accompany each other as light accompanies day. Beauty is maintained in many ways, such as being regularly fed and watered, warm stables in winter, good bedding, and surrounded by men whose dispositions are of a lenient tendency; and the improvement in his condition is very remarkible, if his mind is kept tranquil and easy. IJow graceful the uninterrupted, natural move; how all this miscalled stubbornness vanishes; how willingly he obeys the demands of his master, when by care and ability we recall to real life features that may have long vanished from the scene; when we blend together usefulness and attructiveness in all its various forms. As simple as it may appear on paper, can the well-finished touch of the painter be more gratifying or conducted with more care and skill, spreading as it does over a varied field of transactions in connection with the horse? How if well-treated and restive, being led to water, he will jump, rear, break 
Y\% THE HORSE OF ANOTHER COLOR.

away, and scamper off around the yard. The cultivation of these features does not lie in allowing the horse to move lazily, or working in his own blundering form, but by being guided and steadied by a masterly hand, and is carried out on altogether a different scale than mere feeding and fattening, polished harness, tearing the hide from him with an iron curry-comb, or whipped, with the erroneous endeavor to force life and action.

\section{NOTES ON BREEDING.}

Horse raising at the present day is probally the most uncertain and unsatisfactory of all live stock raising. How seldom do we obtain a type of the sire. How is this? There must be some interruption. By experience, I am led to believe that the American system of working the horse is, as a whole, detrimental to breeding, for the driver may jump into the wagon or sleigh with the reins and drive at a headlong speed without any inconvenience; and will thoughtlessly drive long journeys with a mare probably in an advanced state of carriage. This is not only occasionally, but a mode of travel the mare is daily called upon to en- 
counter, cramping and hindering expansion. How the horse is dereloped in England is a question it would be well for the horse-breeder to pry into. If we look at their mode of working the horse, we find it quite different from that in America. There probalbly the mare, in her whole life, is never once driven out of a brisk walk. I have had some experience in that country, and I may safely say that those mares, otherwise properly cared for and sound, never fail, but bring about the very best breeding results. It is a regular occurrence for them to raise foals that will outgrow the parental stock in mere weight and bulk. If this be the real state of affairs, and there is every reason to believe so, then it looks as thongh it is through their system of working the horse, being more farorable to breeding mares, that stocks their markets with a dereloped assortment of heary draught horses.

\section{GENERAL REMARKS.}

We frequently find writers waiving the ability of the lady in quieting down a restive horse, but it must have escaped their knowledge not to know that the fair sex, after the first few drires, 


\section{4}

THE HORSE OF ANOTHER COLOR.

stand in the rery first ramks of society to effect that end, and they obtain their control simply in this way: the horse finds that extreme measures are not resorted to, he is not driven to extreme action; and it is quite possible that if all horses could be worked by small boys, balky and unmanageable horses would soon vanish from the land from the same simple reason. IIere again we are face to face with the fact that leniency is the best policy.

As a rule, heavy draught teams should not be forced to do much trotting, unless restive and that way inclined, but you will cultivate energy and activity by training them to walk lively, that is, in cold weather, with a light or no load and the horses not tired. This will be accomplished by bracing them up together by a frequent light touch of the whip. Never allow the horses to indulge in a spiritless, slovenly move, except in the heat of summer. At those times the life and energy of the horse vanishes, and he will lag through as best he can. In warm weather do not endeavor to force life by severe whipping, because it cannot be effected; if he is panting give him time or you may cause the death of the horse. 
Many drivers are in the habit of stinting their horses in the use of water with a view to keeping them commonly called tucked up, or, in other words, to prerent bellying down. This must be painful and grievons to the animal and probably injurious to health, and, moreorer, privation is as poison to the gay, cheerful features of the animal. It is frequently found that one horse will not keep even with the other. This scarcely admits of a cure, for if we whip him severely the leader, finding himself out of position, is stealthily endeavoring to keep the lead. The difficulty will be materially diminished by whipping the slow one often and light, with a view to cheer and encourage him to close up to his companion; shortening the slow one's traces will be an improvement. 'L'his case is like two men working together; one will take a leading part in everything, and his companion will, as a rule, give way to it; so we see it is rather the horse's own affair than ours. In traveling along the road the lines should be held in the hand, and not humg on the wagonrack, just sufficiently tight so that the horses are aware of the fact, for in this way we rivet their attention to their work. Do not, by all 
means, use that aggravating, probing word "get up," or singling out by the name. Keep silent, and you will promote attraction and willing contentment. You may give a chirp, but no more.

In descending a hill, if the team cannot stop the wagon, if convenient, cramping them around the crossed position of the front wheels will stop almost any load. Hasty backing of the wagon is another grievance that can scarcely be cured. This habit is probably aggravated by the martingale sawing across the breast, and, moreover, by going slow their strength is retarded and the horse is unpleasantly aware of the danger of sitting down on his haunches, and if we whip him it has no good effect in the way of a cure, for it appears as though the horse recieves it in such a light that he thinks it means to back, and do what we may, the next time he is required to back, the same hasty move is made, and by no ordinary means can we reach the intellect to teach him that the whipping is to prevent hasty backing. In stamping our authority on the horse's memory the starting and stopping words are two promi-

- nent commands the horse should be particu- 
larly tanght to obey. Give the word, to stop and then pull the lines, holding them tight until they stop; thus you will weld the horses to take the breeching together, keeping good order, making their way more pleasant, but do not use that monacing word "back" after the word "whoa," or, for example, "whoa, back." The horse is subject at times to untold-of suffering in the blacksmith shop, more especially at the hands of a journeyman smith employed by companies, and caring but little for the presence of the driver; for it is a common occurrence to cut the clinches, take off the shoe, pick and hammer out the stubs, clean and pare the foot, whilst the helper is preparing nails, heating and fetching on tine shoe. If it does not fit, it is a Godsend for the horse, for he would be expected to stand on one fore or hind leg, with little or no intermission, until the new shoe is on and every thing is complete, which is far too long, and to relieve his aching limb will lean on the smith, for which he is apt to reciere the hammer on his ribs with a sound equal to that produced by striking an empty flour barrel. The horse suffers the most in this way when being shod foreward, especially if the front feet 
stand an inch or two lower than the hind ones, as there is far more weight on the front than on the hind legs. It would be of great service, and more in accordance with the age, if something could be attached to the beams overhead in the smith's shop to receive part of the weight of a tired, tender-footed horse. It is a common occurrence to see the horse so dread the smith and the shop that he cannot be induced to face his doom and has to be backed into the smithery.

When one horse is weaker than the nther, through being wind-broken, foundered, or by other causes, we should endeavor to equalize the draught according to their capacities, by giving the weaker the longer end of the evener, for the sufferings of an ailing horse cannot be ascertained. 'This being the case, we should remember that if our own sufferings and allotted task of labor, under all shades of circumstances, were at the disposal of another, we should not unfrequently find ourselves in a very depressed predicament. "Imagine the sufferings of this noble and fuithful animal, as he toils on," says Chambers, "until he frequently drops down dead through sheer exhaustion, 
urged on by the anger of man and the.terrible scourge of the whip." As a rule, it is thought the horse knows what he is being whipped for, but we should bear in mind that the arerage horse has but little more forecast, has but little more knowledge of ways and means, or how to guard against difficulties, than the wheel of the wagon that he is drawing. As shown, he works according to his accustomed habit, and this is probably all that he knows about work. He is just as liable to take the rery worst places in the road for his own advantage as any other; he is as liable, as not, to run the wheel over a precipice and dash himself and wagon to pieces at the bottom. So narrow is the limit of the horse's knowledge, that in fighting flies, etc., he may hook his head by the check-rein to the other's hames a hundred times daily, but, as a rule, he will never learn the simple trick of unhooking it again; or, feed him with oats, in a box out of doors, and he may turn it over, having to grovel his grain up from the dirt and stones every time, yet he will never have the sagacity to prevent it; in like.manner, he will spill and lose his water. Seeing this, we may 
conclude, upon good grounds, that his intellect is in a very foggy state.

The horse does, certainly, appear somewhat sagacious in many little ways; but this is, as a rule, only a flickering deception. For instance, in surmounting a hill, he will encounter the difficulty with all the vigor peculiar to his race, as though his aim is for some distant accomplishment, but this ambition does not pass farther than his immediate surroundings, produced by the present pinch of the collar. For one minute he may be seen struggling with all his might, and the next he may be seen with one hind leg hanging lazily by the side of the other, remaining inactive for hours, and showing no signs of any impatience. His principal sagacity is found in the way he detects the nature of the voice, whether angry or otherwise; but it is not far to look to find some clue to his knowledge in this matter, for, probably, he is not long in the world before he finds man holding a despotic sway over the animal world, and, as we see, his timid nature causes him a continuous fear when man is nigh. Through this continuous fear, from his early days onward, he becomes thoronghly schooled in detecting the 
humor of man by the tone of the voice; but when we put the harness on and endeavor to teach him to work, we take him into a new field of labor, something that his clouded intellect cannot rightly fathom; and, moreover, if not handled with great care, his thoughts are still groping through its old channels, marring all other learning. Thus again we see the necessity of using leniency. Having nothing to fear from man, his thoughts would be at liberty to dwell on his occupation. I may mention here that there is every reason to believe that the horse, through harsh treatment, becomes so uneasy at the presence of man that he nibbles the manger, etc., for relief; hence the cribbiter.

We frequently find teams that move in a stolid, begrudging manner; this is through being hallooed at and severely whipped on one certain part of the body or legs. It is said that the garroter, after once being sentenced and receiving forty or fifty lashes, will scarcely attempt the crime again, and undergo a repetition, such is the terrible effect. If this be the case, what a life of suffering the horse must be passing through, when, probably, he receives a thou- 
sand or more lashes daily. Some may suppose it is not so severe with the horse as with man, but we should remember blood is frequently drawn, and that is equal to flogging, saying nothing of the vast quantity given; and how are those animals to rest at night and be prepared for the morrow, moaning and groaning under a partly-flayed body in their dark, gloomy stalls, aching out the time and the dreaded approach of day, to be dragged forth only to undergo a repetition of this terrible infliction? The cure: Do not speak to the horses only in turning, and then, in a mild, unprejudiced manner; whip light, smooth and often on varied parts of the back, avoiding that part you have been in the habit of whipping. Following this and instructions elsewhere found, and you will produce a good team out of the remains of a bad one.

There is pointed out in this work much suffering in the horse family, but this is only a part of the misery they are heir to, for we frequently find them doomed to linger out long winters, with its biting spells of frost, in stables so open that they afford no warmth whatever; added to this, he is too often badly fed and 
irregularly watered. Work he is bound to, if required, sick or sore; he must go so long as he keeps his feet; in short, he is compelled to endure a host of grievances that beggar all description, of which legislation is powerless to avert, for probably not more than one suffering animal in ten thousand comes under the notice of the proper authorities; and this one, could he speak, would probably say that the sore they were healing was only a drop in the bucket in comparison with his long years of suffering and torture, of which he has no hope of escape until old age steals upon him, and his once porwerful muscles grow feeble. He is now turned out to shift for himself, to be caught up on busy days; and some stormy night in autumn, in seeking shelter, he mires and dies a martyr's death after long years of toil. Late and early, through fair and foul weather, he has carried his end of the yoke throngh the battles of life, but, alas! this is his reward. Better, far better, for him had this so-called civilization never been born. After all his endeavors to satisfy the never-ending demands of man, he, in a great measure, denies his own sufferings. To obey the will of man he delivers up his whole 
powers, he reserves nothing, and often dies rather than disobey the requests of his master. If such be the sufferings and principal features in the character of the horse, the feelings of that person are not to be envied whoever utters a harsh tone, draws a severe lash, or urges beyond his strength or speed an animal so willing and so obedient, and whose powers have been so essential to human progress.

\section{THE STABLE.}

When you enter the stable give the horses their feed, and if you keep them waiting do not whip them if they become impatient and paw the floor or kick the partition, or they will bear ill-will towards you. Some horsemen are in the habit of teasing their horses to an exceeding high pitch and then claim that a stranger cannot approach them only at the risk of a kick or bite. The reason of this is the horse makes more bold with a stranger, but to come to the point, he has far more hatred for the person who first teases him and then turns around and resorts to the fiendish act of whipping him should he make too bold in pursuing the very identical course he is taught and it is intended 
he should do. This teasing is thought to be play for the horse, but we should remember his play consists in galloping, rearing, jumping and kicking, and is altogether of a more developed, grander scale, and such petty, insignificant folly he detests. Treat the horse in a proper manner, and as he turns his head around to bite you, give him a moderate, straight poke in the nose and debar the act, but do not do this if you still continue to tease him, for, finding he cannot use his mouth with safety, he will become more exasperated and adopt the use of his heels.

\section{ON CLEANING.}

Tradition has it that cleauing is half feed for the horse, but this is all moonshine, for no amount of cleaning will ever fill the animal's belly. A clean horse, like a man with a clean face, appear's more respectable, but, in either case, the benefit is about on a par. There is no doubt but all clotted dirt should be removed, accompanying a brush-down, but after this I believe man's time could be occupied in far more remunerative occupation in the heat of summer, when the horse is sweating profusely 
and cannot be cleaned in the usual way with brush and comb. There is no doubt that washing, especially the shoulders, in moderately cool water is very refreshing after you allow him to cool off somewhat from the heat of his labors, but if the coat is dry it would be very annoying and unpleasant, the horse being in nowise a water animal. Whale-oil soap is said to be the best, and a lather of it left on the coat will keep off the flies for the night. Dust will appear in chilly fall weather, and the hor'se's coat will stand on end; as this can scarcely be avoided, wiping with a damp sponge or cloth will be beneficial.

Do not whip the horse if he does not like the curry-comb, for you are hurting him, or have been in the habit of so doing. 'The comb, to . some horses, is very annoying, and to use it on such horses any length of time, morning and night, is, I believe, far more injurions than otherwise, having to gobble their feed under a tormenting interruption. Strong-fed horses, in hot weather, will become scaly under the belly, followed by at least an itching annoyance, caused mainly by the curry-comb repeatedly tearing the surface of the skin. To such horses 
it would be a happy relief if a curry-comb were never brought into the stable. The comb is ill-adapted, and should not be allowed to go near this thin-skinned part of the body.

There is reason to believe that separate stalls and plenty of bedding will help to improve the condition of the horse, for double stalls, as a rule, are not roomy enough to admit of both lying stretched out together; consequently, one has to stand; he cannot rest properly in this way, will go to sleep and fall, and, in saving himself, will trample on the other's feet, legs, etc.; the lying one, after experiencing this a few times, will probably refuse to lie down again, or, at least, he cannot rest properly, as he has to keep one eye open for these mishaps, so that both are cramped into a position that forbids proper and refreshing rest. Many timid hor'ses will never lie down while in close proximity to another horse, but will immediately accept the offer when the difficulty is removed.

\section{ON THE HARNESS.}

If there is anything to impair the adaptability of the horse, it is found in the construction of the shoulder, for there is where all of his 
great strength and weight of dranght is brought to bear. We find in a continuous slip-slide, galling commotion and the wholesale suffering daily going on around us in this respect is enough to invite the attention of all who have a feeling for the sufferings of the animal world, and there are reasons to fear that this state of affairs will long exist, unless some important change is made in the shape and the material now in use for the construction of horse-collars; for the present collar is too voluptuous, causing heat and preventing the free working of the shoulderblade. But how this is to be remedied is a question difficult to answer. It seems we are compelled to have a collar sufficiently bulky, so as to spread the draught out from the horse's sides, but I contend, above and below this, we could dispense with a great deal of the present encumbrance. 'There are many reasons for condemning the collars now in use, for, with little observation, it is seen that the main work is in the outer shoulder, or that farthest from the neck, where the present voluptuous collar now bears, making it altogether ill-adapted for its use. The present collar fits all right while standing, but all wrong when in motion, the 
bearing being too wide. I contend that three inches of a soft-bearing, pinching close in to the sides of the neck, and up and down the depth of the shoulder, would be ample for all modern requirements. Added to this, bulky hair padding is in use; soft it is, no doubt, but in regard to heat it is only adding fuel to the fire, and if any galling takes place, extra padding is added and placed crosswise at the shoulderblade, whereas it should be placed up and down, but not to bear on the sore. Our harness will never be in a satisfactory state, until material is found to prevent galling in any way.

Put on in the most hurried fashion, next comes the hames, which are, in adaptability, but little better than the collar. As a rule, they are made with the draught far too low, for, along with what has already been pointed ont, we find that the working scope of the shoulder materially increases down to the point near which the draught now bears, caused by the present shape of the hames. T'hus it appears that the draught cannot be reasonably too high; for heavy work it is quite likely the better place for the dranght to come would be in the vicinity or extreme hollow of the neck, and by 
having the draught high, another important benefit is gained. 'The bulkiness of the collar' is not required to bolster out the traces, as the shoulders become more narrow upwards.

\section{CHOKING-CAUSE AND CURE.}

Choking arises from two causes: either the collar is not deep enough to clear and prevent pressing against the wind-pipe and stopping the wind, or else the belly-band is allowed to remain too slack, allowing the traces to rise in drawing, causing the collar to rise also and press against the wind-pipe and so produce choking. 'The horse is very apt to choke, unless great care is taken to prevent it, as the sloping shape of the shoulder facilitates the rising and pressing of the collar against the wind-pipe. Our ancestors invented the bellyband, no doubt, for the sole purpose to prevent choking, but their children to-day are sadly wanting in knowledge as to its real value. It would be an improvement for heavy work to have the belly-band four or five inches wide, made of one strong piece of pliable leather, and not the hard, narrow, hurtful kind now used. 'Thus we see the horse requires a deep, 
marrow collar-clraught, bearing rather high, and the belly-band arranged so as to check the collar from rising with the draft, and the choking will be cured.

Hames, as a rule, are worn too wide at the top, allowing the whole weight of the pole to sag dows and bear on the top of the neck, whereas they should be more tight and snug, preventing mash and galling. As stated elsewhere, the horse wishes to attack his load with at sudden vigor. This is usually forbidden him, for fear of breaking the tackling, but his harness should be sufficient, and more than sufficiently strong to withstand his most determined efforts. The horse will not injure himself in drawing, if sound and he has good footing, but if anything gives way, in floundering to save himself, he shakes his whole frame and he probably receires more injury than is at the time detected. For various reasons, the harness should be all kept in good repair, for if one part gives way it is apt to carry something else with it, as the horse frequently becomes frightened and unmanageable. 


\section{HEAD FIXINGS.}

As this work shows, the horse requires some steadiness, and, with this in view, check-reins are beneficial, as it steadies and prevents a giddy maneuvering of the head, but it should not be drawn up too tight, or it destroys the spirited movement of the horse. If the horse twitches his head, or parws the ground when standing, he is checked too tight, still he may be suffering somewhat without either being detected. Blind-bridles should be at all times worn, for otherwise we cannot fasten the horse's attention to his work, for it will be on the motion of the whip and the driver, in spite of all that can be done to prevent it; and, moreover, we have altogether too slippery a hold, the horse having things too much his own way, shooting ahead when the whip is coming, and abruptly slackening again the moment it is withheld, defying a smooth, orderly gait of travel. Open-bridles are injurious, and a nuisance to both horse and man. Some claim that open-bridles prevent the shy, but when the nature of the animal is taken into account, such assertions are altogether wanting a fundamental sumport, for, destroy the shy and we destroy the 
pith of the animal, and if the shy is cured by wearing open-bridles, it is brought about through a grinding hatred that is most sure to exist while they are used, and this hatred means hard knocks, and hard knocks rivets the horse's attention on the driver in place of being at liberty to boldly observe his surroundings. And even should it prevent the shy, the shy is only occasional, whereas the blind-bridle is a continuous necessity. With open-bridles we disfigure and destroy the usefulness of the horse, lessen our authority, breed disorder and tend largely to produce balk; therefore they should not be used.

The bridle-head is often sadly neglected, is thoughtlessly worn too short, being pushed over the ears, drawing up the lips; and being worn in this distressing manner continually, is both painful and destructive to a spirited movement, causing sore and tender mouth. The bridlehead should be sufficiently long for the bit to clear the connection of the lips, a half an inch. If the horse be one of those not inclined to shy, use a common or straight smooth snafflebit; in this way you will enhance the horse's pulling on the lines, so much admired and a 
94 THE HORSE OF ANOTHER COLOR.

real necessity in the way of a set-off in a drive. All the harmess should be arranged so as to fit snug and close ; this will enhance a gay, graceful move. The breechings should cross just below the points of the hind-quarters, and no longer than to allow the traces to hook with convenience. This gives the horse more power to hold back and catch his load with precision and adaptness, and prevents the neck-yoke from slipping off the end of the wagon-pole. Our arrangements for holding and backing at present are far from what could be desired; the horse abominably hates the martingale sawing and pressing against his breast, a place altogether too tender to receive the full force of the horse's powers in holding or backing a load; and, to make matters worse, our martingale is too narrow and hard. 'The horse in backing shows he is being hurt, for in backing he is seen to half rear, which throws the greater part of his weight on the hind legs, quite the reverse of where it should be. When hitched to the cart and no martingale is used, this rearing disappears. Breechings should be at all times supplied when harnessed to the wagon, for it is 
terribly pestering to the horse to have to hold or back the wagon, for the belly-band cuts in through the cavities of the fore-arms, and there is reason to believe the horse frequently receives injury from this cause. Again we find reasons for condemning our present backing apparatus. In descending a hill, if the neck-yoke should break, rings draw or break, or breast-straps break, etc., we at once lose all power in steering or controlling the wagon. For many reasons there is no doubt shafts would be an improvement, for with them the horse could not only steer the wagon, but most, if not all, of the above-mentioned grievances would be removed; and, again, the shafts would be carried by the back, whereas the pole is now carried by the neck, where it ought not to be, as it tends to bend the animal down, impairing an upright, attractive carriage.

Flies in the summer season are no doubt very annoying to the horse. Do not whip him harshly for any act he may do in fighting them, or it will impair the confidence he should have in you ; and free all entanglements without a murmur, for we should remember the horse has 
not the means or the knowledge to lift the remotest article. Some protection from the flies should be provided on the forward part of the body where the tail cannot reach, more especially just at the back of the fore-arms, for here he is likely to receive the main attack. 

